Available online on 15.07.2018 at http://jddtonline.info
Open Access to Pharmaceutical and Medical Research
commercial use, provided the original work is properly cited

Open $\odot$ Access

Research Article

\title{
GC-MS ANALYSIS, ANTIOXIDANT AND ANTIBACTERIAL ACTIVITIES OF ETHANOL EXTRACT OF LEAVES OF AEGLE MARMELOS (L.) CORRÊA
}

\author{
Arumugam Perumal $^{* 1}$, Saraswathi Krishna ${ }^{2}$, Madhusree ${ }^{3}$ \\ ${ }^{1}$ Armats Biotek Training and Research Institute, Maduvinkarai, Guindy, Chennai - 600 032, India \\ ${ }^{2}$ Karpaga Vinayaga College of Engineering and Technology, Madhuranthagam, Kancheepuram - 603 308, India \\ ${ }^{3}$ Meenakshi College for Women, Kodambakkam, Chennai - 600 024, India
}

\begin{abstract}
The aim of the present study was to evaluate the antioxidant activities of leaves of Aegle marmelos and to identify the bioactive compounds by performing GC-MS analysis resulting in the presence of volatile and semi volatile compounds. The $\mathrm{IC}_{50} \mathrm{of} \mathrm{DPPH}^{\circ}$ radical scavenging assay was $78.36 \mu \mathrm{g} / \mathrm{mL}$ concentration respectively. Also, the $\mathrm{IC}_{50}$ of Phosphomolybdenum reduction and ferric reducing power assay were 41.35 and $20.58 \mu \mathrm{g} / \mathrm{mL}$ concentration respectively. Also, total phenolic and flavonoid content were determined, in which flavonoids were found to be predominantly higher. The results of this study portray the effective antioxidant activity of Aegle marmelos and further studies are required to isolate the active compounds from various parts of this species and their mode of action. From the study it can be concluded that the plant might be promising as a curative for many diseases associated with free radicals.
\end{abstract}

Keywords: Free radicals, Aegle marmelos, Antioxidant, Dot plot, $\mathrm{DPPH}{ }^{*}$ assay, $\mathrm{IC}_{50}$, GCMS.

Article Info: Received 07 May, 2018; Review Completed 28 June 2018; Accepted 01 July 2018; Available online 15 July 2018

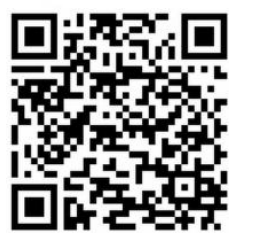

Cite this article as:

Arumugam P, Saraswathi K, Madhusree, GC-MS Analysis, antioxidant and antibacterial activities of ethanol extract of leaves of Aegle marmelos (L.) corrêa, Journal of Drug Delivery and Therapeutics. 2018; 8(4):247-255 DOI: http://dx.doi.org/10.22270/jddt.v8i4.1781

\section{*Address for Correspondence:}

Arumugam Perumal, Armats Biotek Training and Research Institute, 14/18C, Link road, Mettu street, Maduvinkarai, Guindy, Chennai $-600032$.

\section{INTRODUCTION}

Aegle marmelos is a perennial tree, wild in the sub Himalaya tract, central and South India. This plant is commonly called as Beal in Hindi, Vilvam in Tamil and Bilva in Sanskrit. It belongs to the family Rutaceae. It is indigenous to India and is used in folk medicines. The Ayurvedic practitioners use almost all of their parts but the greatest medicinal value ascribed to its fruits. Oxidative stress is produced during normal metabolic process in the body as well as induced by the variety of environmental and chemical factors which cause generation of various reactive free radicals and subsequent damage to macromolecules like DNA, Proteins and Lipids ${ }^{1}$.

Bael having useful medicinal properties especially as a cooling agent is a deciduous sacred tree, associated with Gods. This tree is popular in Shiva and Vishnu temples also popularly known as temple garden plant and it can be grown in every house. Its leaves are trifoliate symbolizing the Thri-murthies- Brahma, Vishnu, Shiva with spear shaped leaflets resembling trisoolam the weapon of Lord Shiva ${ }^{2}$. Aegle marmelos is a slowgrowing, medium sized tree, 25 to 30 feet tall. The stem is short, thick, soft, flaking bark, and spreading, sometimes spiny branches, the lower ones drooping. There are sharp, axial one inch long spikes on this tree. The leaflets are oval or lancet shaped, 4-10 cm long, 2-5 $\mathrm{cm}$ wide. Leaves composed of 3 to 5 leaflets in it. The lateral leaflets are without petiole and the terminal one has a long one. The petiole is 1 to 2.5 inch long. Fruit is spherical or oval in shape with a diameter of 2 to 4 inch. Shell is thin, hard and woody in nature. It is greenish when unripe and upon ripening it turns into yellowish colour. The pulp of the fruit has 8 to 15 segments. The 
pulp is yellow, soft, pasty, sweet, resinous and fragrant ${ }^{3}$,

\section{MATERIALS AND METHODS}

Collection of plant material and preparation of extracts

The leaves of Aegle marmelos were carefully washed with tap water followed by rinsing in distilled water and air-dried at room temperature for few hours. Then leaves were separated and taken to separate clean place and dried at room temperature for one week. Then they were ground into fine powder and sieved through fine mesh, finally stored in cool and dry place in a clean air-tight container. Extraction of leaf powder with Hexane, Ethyl acetate, Aqueous, Methanol and Ethanol was performed by direct method ${ }^{5}$.

\section{Antioxidant activity by dot-blot DPPH staining method}

Drops of DPPH $(0.4 \mathrm{~mm})$ solution in methanol were loaded onto a $5 \mathrm{~cm} \times 5 \mathrm{~cm}$ TLC plate (silica gel 60 F254; Merck) in each column and allowed to dry for 2 minutes. The first row of TLC plate was considered as control, containing only DPPH. Different extracts of Aegle marmelos of various concentrations was carefully loaded onto the DPPH spot in second-fifth row. The sixth row of TLC plate was considered as standard reference, where ascorbic acid was carefully loaded onto the DPPH spot $^{6}$. Stained silica gel layer revealed a purple background with yellow or white spots at the location where radical scavenging capacity observed.

Invitro Antioxidant activity of various extracts of Aegle marmelos

\section{(a) Free radical Scavenging Activity}

The antioxidant activity was determined by DPPH scavenging assay ${ }^{7}$ in which various concentrations of five different crude extracts was been pipetted out in clean test tubes. Freshly prepared DPPH (1, 1-Diphenyl2-picryl hydrazyl) solution ( $1 \mathrm{~mL})$ was added to each tube and the samples were incubated in dark at $37^{\circ} \mathrm{C}$ for 20 mins and read at $517 \mathrm{~nm}$. The data were expressed as the percent decrease in the absorbance compared to the control. Ascorbic acid was used as reference compound. The percentage inhibition of radical scavenging activity was calculated.

\section{$\%$ Radical scavenging potential $=$ \\ [(Control OD-Sample OD)/Control OD] X100.}

\section{(b) Phosphomolybdenum reduction assay}

Total antioxidant capacity can be calculated in which various concentrations of five different extracts from the prepared sample $(1 \mathrm{mg} / \mathrm{mL})$ was been pipetted out ${ }^{8}$ and $1 \mathrm{~mL}$ of the reagent solution was added, followed by incubation in boiling water bath at $95^{\circ} \mathrm{C}$ for $90 \mathrm{mins}$. After cooling the sample to room temperature, the absorbance of the solution was measured at $695 \mathrm{~nm}$ in UV spectrophotometer. A typical blank solution contained $1 \mathrm{~mL}$ of reagent solution and the appropriate volume of the same solvent used for the sample and it was incubated under same conditions. Ascorbic acid served as standard.

$\%$ Phosphomolybdenum reduction $=$

[(Sample OD-Control OD)/Sample OD] X100.

\section{(c) Ferric $\left(\mathrm{Fe}^{3+}\right)$ reducing power assay}

The five different crude extracts was taken in various concentrations and was mixed with $2.5 \mathrm{~mL}$ of phosphate buffer (0.2M, pH-6.6) and $2.5 \mathrm{~mL}$ of potassium ferricyanide $(1 \% \mathrm{w} / \mathrm{v})$, and incubated at $50^{\circ} \mathrm{C}$ for 30 mins. Then, $2.5 \mathrm{~mL}$ of trichloroacetic acid $(10 \% \mathrm{w} / \mathrm{v})$ was added to the mixture and then centrifuged at 3000 rpm for 10 mins. Finally, $2.5 \mathrm{~mL}$ of upper layer solution was mixed with $2.5 \mathrm{~mL}$ of distilled water and $0.5 \mathrm{~mL}$ $\mathrm{FeCl}_{3}(0.01 \% \mathrm{w} / \mathrm{v})$ and the absorbance was measured at $700 \mathrm{~nm}^{9,10}$. Ascorbic acid served as standard. Based on the antioxidant study results, one potent extract would be evaluated for further analysis.

$\%$ Ferric Reducing Potential $=$

[(Sample OD-Control OD)/Sample OD] X100.

Qualitative phytochemical analysis of Aegle
marmelos

Screening of phytochemicals for Aegle marmelos was carried out comparatively using standardized methods ${ }^{5}$.

Quantitative estimations of total phenol and flavonoids

\section{Determination of total Phenols}

Folin-Ciocalteau reagent method was used to determine the total phenolic compounds ${ }^{11}$ with slight modifications. One hundred $\mu \mathrm{L}$ of selected extract $(1 \mathrm{mg} / \mathrm{mL})$ (leaves of selected extract of Aegle marmelos) was mixed with $900 \mu \mathrm{L}$ of distilled water and $1 \mathrm{~mL}$ of Folin-Ciocalteau reagent (1:10 diluted with distilled water). After 5 mins, $1 \mathrm{~mL}$ of $\mathrm{Na}_{2} \mathrm{CO}_{3}(20 \% \mathrm{w} / \mathrm{v})$ solution was added. The mixture was then allowed to stand for 30 mins incubation in dark at room temperature. The absorbance was measured by UV-vis spectrophotometer at $765 \mathrm{~nm}$. The total phenolic content was expressed in terms of gallic acid equivalent $(\mu \mathrm{g} / \mathrm{mg}$ of extract), which is a common reference compound.

\section{Determination of total flavonoids}

The total flavonoid content of leaves of selected extract of Aegle marmelos was determined using aluminium chloride reagent method with slight modification ${ }^{12}$. Five hundred $\mu \mathrm{L}$ of extract $(1 \mathrm{mg} / \mathrm{mL})$ was mixed with $0.5 \mathrm{~mL}$ of methanol and $0.5 \mathrm{~mL}$ of $(5 \% \mathrm{w} / \mathrm{v})$ sodium nitrite solution. Then, $0.5 \mathrm{~mL}(10 \% \mathrm{w} / \mathrm{v})$ aluminium chloride solution was added followed by $1 \mathrm{~mL}$ of $1 \mathrm{M} \mathrm{NaOH}$. The mixture was incubated for 30 minutes at room temperature and the absorbance was measured at 510 $\mathrm{nm}$. The result was expressed as $(\mu \mathrm{g} / \mathrm{mg}$ of extract) quercetin equivalent.

\section{Thin layer chromatography analysis}

Thin layer chromatography (TLC) analysis was carried out for selected extract of Aegle marmelos on silica gel aluminium sheet (Merck Silica gel 60 F254) ${ }^{13}$. The selected extract was spotted at $0.5 \mathrm{~mm}$ above from the 
bottom of the TLC plate. The spotted TLC plate was placed in a $100 \mathrm{~mL}$ beaker containing solvent mixture. The chromatogram was developed and the spots were visualized under UV light at $254 \mathrm{~nm}$ as well as in iodine vapour. The ratio in which distinct coloured bands appeared was optimized and $\mathrm{R}_{\mathrm{f}}$ values were calculated.

$$
\mathrm{R}_{\mathrm{f}}=\frac{\text { Distance travelled by the solute }}{\text { Distance travelled by the solvent }}
$$

\section{Screening of crude extract for antibacterial activity}

\section{Agar Well diffusion assay}

Nutrient agar was prepared and poured in the sterile petri dishes and allowed to solidify. 24 hours grown bacterial pathogens were swabbed on nutrient agar plates ${ }^{14}$. Then, the stock crude of selected extract individually $(10 \mathrm{mg} / \mathrm{mL})$ was prepared. Varying concentration $(250 \mu \mathrm{g}, 500 \mu \mathrm{g}, 750 \mu \mathrm{g}$ and $1000 \mu \mathrm{g})$ of plant extract was loaded in the wells made using cork borer. Tetracycline was used as standard. The plates were then incubated at $37^{\circ} \mathrm{C}$ for 24hours. After incubation the inhibition diameter was measured using zone scale.

Identification of bioactive compounds by Gas chromatography-Mass spectrometry analysis

The presence of active compounds were been confirmed by thin layer chromatography and the compounds were identified using gas chromatography and mass spectrometry (GC-MS) method, (TSQ QUANTUM XLS). The name of the instrument is Gas Chromatography-Mass Spectrometry and the instrument made is of Thermo scientific. The software required for analytical studies is XCALIBUR (ver-2.2). The column size is of TG-5MS (30mX0.25mmX0.25um). The injector temperature and interface temperature $\left({ }^{\circ} \mathrm{C}\right)$ was at $280^{\circ} \mathrm{C}$.

\section{RESULTS AND DISCUSSION}

\section{Collection and preparation of plant sample}

The Aegle marmelos leaves were collected from shiva temple in nearby surroundings. The leaves were then separated and shade dried for ten days in a wellventilated room at $37^{\circ} \mathrm{C}$ and ground to coarse powder using the mechanical grinder. After 72 hours of extraction, the individual extract supernatant was filtered by filter paper and condensed in a rotary evaporator at $50^{\circ} \mathrm{C}$, which yields gummy extract. The extracted residues were weighed and re-dissolved in different solvents to yield $1 \mathrm{mg} / \mathrm{mL}$ as final volume for further analysis.

\section{Screening of radical scavenging activity by dot-blot DPPH staining method}

The results of dot-blot assay showed active spots in which various concentrations of five different extracts of Aegle marmelos were placed in respective rows. The zone exhibiting purple colour indicates that there is no antioxidant (free radical scavenging) activity and the zone exhibiting yellow colour indicates antioxidant activity. From the results obtained (Figure 1), it is evident that ethanol extract of Aegle marmelos has effective antioxidant activity, when compared to other extracts, also compared as well as standard ascorbic acid.

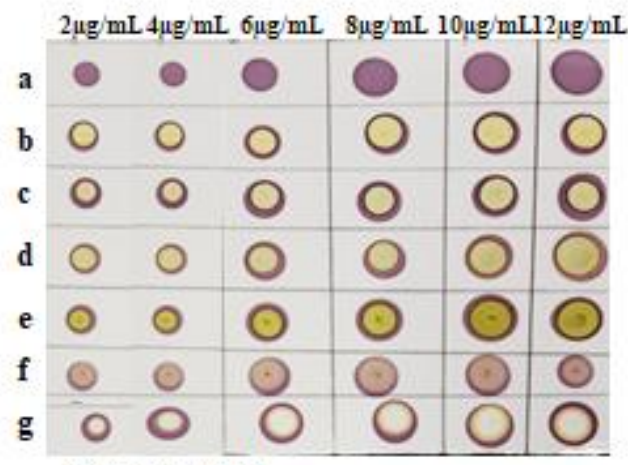

(a) Control - DPPH

(b) DPPH + Hexane extract

(c) DPPH + Ethyl acetate extract

(d) DPPH + Methanol extract

(e) DPPH + Ethanol extract

(f) DPPH + Aqueous extract

(g) DPPH + Ascorbic acid (standard)

Figure 1: Dot-blot assay of different extracts of Aegle marmelos

The ethanol extract of Aegle marmelos was spotted on each row in which the colour changes from purple to yellow or white was well observed indicating potent antioxidant activity when compared to standard Ascorbic acid.

Invitro Antioxidant activity of various extracts of Aegle marmelos

\section{(a) Free radical Scavenging Activity}

Antioxidant molecules can quench DPPH free radicals (i.e by providing hydrogen atoms or by electron donation, via a free radical attack on the DPPH molecule) and convert them to colourless. The percentage of DPPH scavenging activity was $93.67 \%$ in ethanol fraction (Table 1) of Aegle marmelos when compared to other four fractions (Table $2 \& 3$ ). The $\mathrm{IC}_{50}$ value was found to be $78.36 \mu \mathrm{g} / \mathrm{mL}$ concentration (Graph $1,2 \& 3$ ) and was compared with standard (Ascorbic acid, $\mathrm{IC}_{50}$ value as $11.98 \mu \mathrm{g} / \mathrm{mL}$ concentration).

The antioxidant activity for five different extracts (Methanol, Ethanol, Aqueous, Ethyl acetate and Hexane) of Aegle marmelos was determined by DPPH scavenging assay. The radical scavenging activity was well observed for ethanol extract in which 1,1-diphenyl2-picryl hydrazyl was reduced to 1,1-diphenyl-2-picryl hydrazine.

Table 1: Radical scavenging activity by DPPH assay for ethanol extract of Aegle marmelos

\begin{tabular}{|l|c|c|}
\hline \multirow{2}{*}{ S.No } & $\begin{array}{c}\text { Concentration } \\
(\boldsymbol{\mu} \mathbf{g} / \mathbf{m L})\end{array}$ & $\begin{array}{c}\text { Radical scavenging } \\
\text { activity }\end{array}$ \\
\cline { 3 - 3 } & & Ethanol extract \\
\hline $\mathbf{1 .}$ & 50 & 24.90 \\
\hline $\mathbf{2 .}$ & 60 & 36.36 \\
\hline $\mathbf{3 .}$ & 70 & 44.66 \\
\hline $\mathbf{4 .}$ & 80 & 54.37 \\
\hline $\mathbf{5 .}$ & 90 & 66.79 \\
\hline 6. & 100 & 93.67 \\
\hline
\end{tabular}


Table 2: Radical scavenging activity by DPPH assay for ethyl acetate and aqueous extract of Aegle marmelos

\begin{tabular}{|l|c|c|c|}
\hline S.No & $\begin{array}{c}\text { Concentration } \\
(\boldsymbol{\mu g} / \mathbf{m L})\end{array}$ & \multicolumn{2}{|c|}{$\begin{array}{c}\text { Radical scavenging } \\
\text { activity }\end{array}$} \\
\cline { 3 - 4 } & & $\begin{array}{c}\text { Ethyl acetate } \\
\text { extract }\end{array}$ & $\begin{array}{c}\text { Aqueous } \\
\text { extract }\end{array}$ \\
\hline 1. & 20 & 18.34 & 33.64 \\
\hline 2. & 40 & 22.60 & 37.34 \\
\hline 3. & 60 & 27.96 & 39.19 \\
\hline 4. & 80 & 33.42 & 41.04 \\
\hline 5. & 100 & 41.83 & 42.28 \\
\hline 6. & 120 & 43.27 & 68.20 \\
\hline
\end{tabular}

Table 3: Radical scavenging activity by DPPH assay for hexane and methanol extract of Aegle marmelos

\begin{tabular}{|l|c|c|c|}
\hline S.No & $\begin{array}{c}\text { Concentration } \\
(\boldsymbol{\mu} \mathbf{g} / \mathbf{m L})\end{array}$ & \multicolumn{2}{|c|}{$\begin{array}{c}\text { Radical scavenging } \\
\text { activity }\end{array}$} \\
\cline { 3 - 4 } & & $\begin{array}{c}\text { Hexane } \\
\text { extract }\end{array}$ & $\begin{array}{c}\text { Methanol } \\
\text { extract }\end{array}$ \\
\hline 1. & 50 & 12.82 & 21.63 \\
\hline 2. & 100 & 18.06 & 26.42 \\
\hline 3. & 150 & 21.22 & 38.19 \\
\hline 4. & 200 & 26.81 & 43.68 \\
\hline 5. & 250 & 31.20 & 47.06 \\
\hline 6. & 300 & 33.40 & 54.41 \\
\hline
\end{tabular}

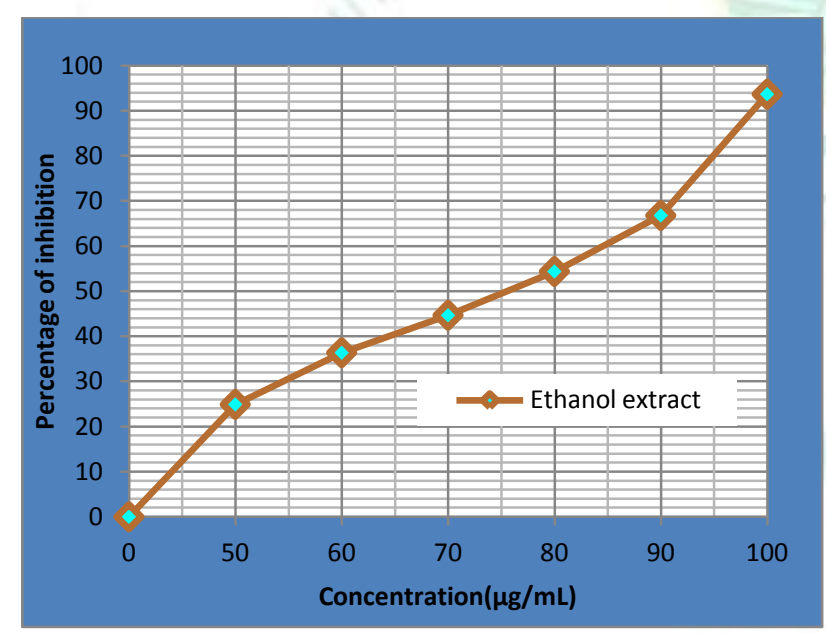

Graph 1: Radical scavenging activity by DPPH assay for ethanol extract of Aegle marmelos

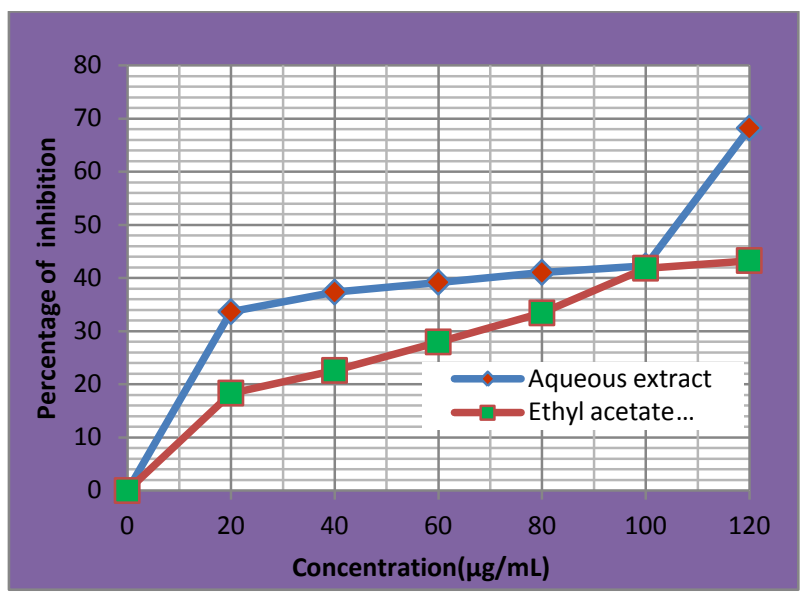

Graph 2: Radical scavenging activity by DPPH assay for aqueous and ethyl acetate extract of Aegle marmelos

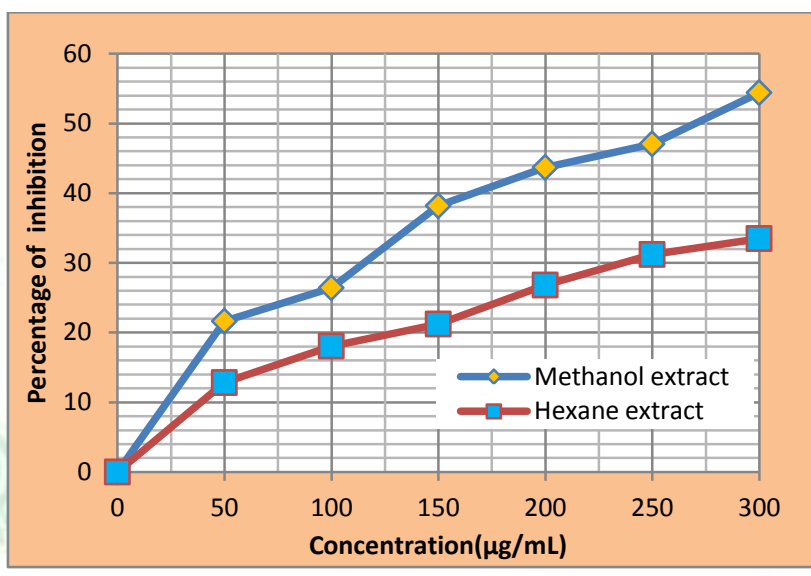

Graph 3: Radical scavenging activity by DPPH assay for hexane and methanol extract of Aegle marmelos

\section{(b) Phosphomolybdenum reduction assay}

The total antioxidant activity of ethanol extract of Aegle marmelos was measured spectrophotometrically by phophomolybdenum reduction method which is based on the reduction of Mo (VI) to Mo (V) by the formation of green phosphate/Mo (V) complex at acidic $\mathrm{pH}$, with a maximum absorption at $695 \mathrm{~nm}$. The maximum reducing ability for ethanol extract was higher as $67.83 \%$ at $120 \mu \mathrm{g} / \mathrm{mL}$ concentration, when compared to other extracts (Graph 4). The experiment demonstrated higher antioxidant activity the $\mathrm{IC}_{50}$ of $41.35 \mu \mathrm{g} / \mathrm{mL}$ concentration (Table 4) and was compared with standard Ascorbic acid $\left(\mathrm{IC}_{50}=23.28 \mu \mathrm{g} / \mathrm{mL}\right.$ concentration $)$.

Table 4: Phosphomolybdenum reduction for five different extracts of Aegle marmelos

\begin{tabular}{|c|c|c|c|c|c|c|}
\hline \multirow{2}{*}{ S.No } & $\begin{array}{c}\text { Concentration } \\
(\boldsymbol{\mu g} / \mathbf{m L})\end{array}$ & \multicolumn{5}{|c|}{ Percentage of phosphomolybdenum reduction } \\
\cline { 3 - 7 } & & $\begin{array}{c}\text { Hexane } \\
\text { extract }\end{array}$ & $\begin{array}{c}\text { Ethyl acetate } \\
\text { extract }\end{array}$ & $\begin{array}{c}\text { Aqueous } \\
\text { extract }\end{array}$ & $\begin{array}{c}\text { Methanol } \\
\text { extract }\end{array}$ & $\begin{array}{c}\text { Ethanol } \\
\text { extract }\end{array}$ \\
\hline 1 & 10.03 & 19.22 & 38.91 & 31.28 & 41.62 \\
\hline 2 & 20 & 13.16 & 23.61 & 43.52 & 42.64 & 48.36 \\
\hline 3 & 40 & 19.38 & 29.42 & 46.08 & 44.81 & 53.08 \\
\hline 4 & 60 & 24.79 & 34.78 & 52.96 & 47.13 & 55.27 \\
\hline 5 & 80 & 29.32 & 36.22 & 54.23 & 52.04 & 64.92 \\
\hline 6 & 100 & 34.56 & 42.83 & 57.14 & 55.32 & 67.83 \\
\hline
\end{tabular}




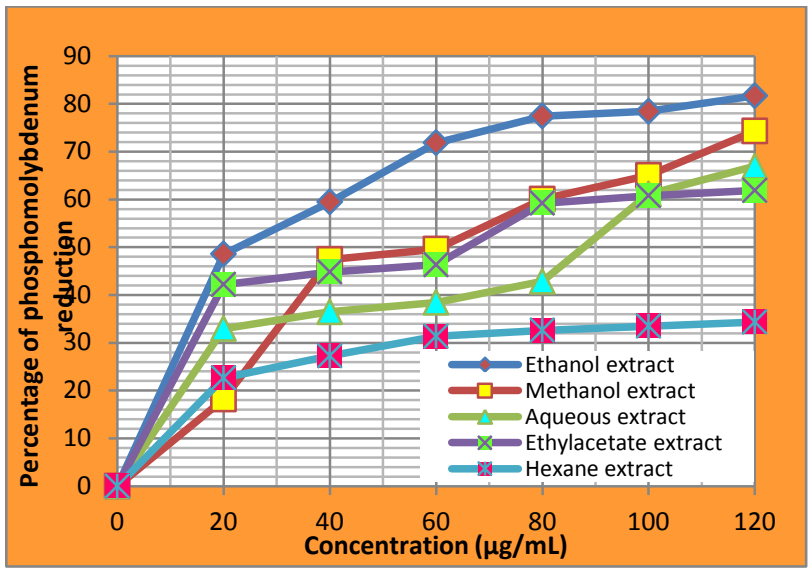

Graph 4: Phosphomolybdenum reduction for five different extracts of Aegle marmelos

\section{(c) Ferric $\left(\mathrm{Fe}^{3+}\right)$ reducing power assay}

Five different extracts of Aegle marmelos react with Potassium ferricyanide and ferric chloride there by gets reduced to Potassium ferrocyanide and ferrous chloride $\left(\mathrm{Fe}^{3+}\right.$ to $\left.\mathrm{Fe}^{2+}\right)$ turning to various shades of green. The reducing power of $\mathrm{Fe}^{3+}$ to $\mathrm{Fe}^{2+}$ by ethanol extract of Aegle marmelos was studied and showed reduction ability in a dose dependent manner (Graph 5). The maximum reduction for ethanol extract of Aegle marmelos was $81.70 \%$ at $120 \mu \mathrm{g} / \mathrm{mL}$ concentration (Table 5). The $\mathrm{IC}_{50}$ value for ethanol extract of Aegle marmelos was found to be $20.58 \mu \mathrm{g} / \mathrm{mL}$ concentration and was compared with the standard $(29.11 \mu \mathrm{g} / \mathrm{mL}$ concentration) Ascorbic acid.

Table 5: Ferric reducing activity for five different extracts of Aegle marmelos

\begin{tabular}{|c|c|c|c|c|c|c|}
\hline \multirow{2}{*}{ S.No } & \multirow{2}{*}{$\begin{array}{c}\text { Concentration } \\
(\boldsymbol{\mu g} / \mathbf{m L})\end{array}$} & \multicolumn{5}{|c|}{ Percentage of ferric reducing potential } \\
\cline { 3 - 7 } & & $\begin{array}{c}\text { Hexane } \\
\text { extract }\end{array}$ & $\begin{array}{c}\text { Ethyl acetate } \\
\text { extract }\end{array}$ & $\begin{array}{c}\text { Aqueous } \\
\text { extract }\end{array}$ & $\begin{array}{c}\text { Methanol } \\
\text { extract }\end{array}$ & $\begin{array}{c}\text { Ethanol } \\
\text { extract }\end{array}$ \\
\hline 1 & 20 & 42.21 & 32.98 & 18.21 & 48.59 \\
\hline 2 & 40 & 27.27 & 44.82 & 36.47 & 47.43 & 59.49 \\
\hline 3 & 60 & 31.36 & 46.33 & 38.46 & 49.60 & 71.86 \\
\hline 4 & 80 & 32.63 & 59.23 & 42.85 & 60.06 & 77.46 \\
\hline 5 & 100 & 33.50 & 60.79 & 61.15 & 65.02 & 78.43 \\
\hline 6 & 120 & 34.35 & 61.90 & 66.92 & 74.32 & 81.70 \\
\hline
\end{tabular}

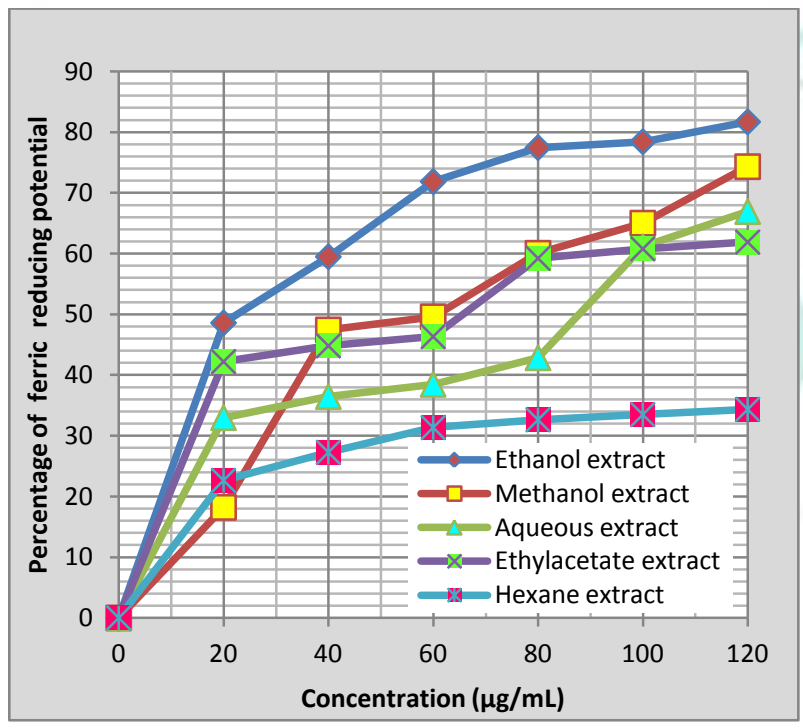

Graph 5: Ferric reducing activity for five different extracts of Aegle marmelos

\section{Qualitative Phytochemical analysis}

Based on the antioxidant activity results, ethanol extract was selected for further mode of research. The qualitative analysis for Ethanol extract of Aegle marmelos was performed based on standardized methods.
Table 6: Qualitative analysis of ethanol extract of Aegle marmelos

\begin{tabular}{|c|l|l|}
\hline S.No & Phytochemical & Results \\
\hline 1. & Resins & Positive \\
\hline 2. & Proteins & Positive \\
\hline 3. & Flavonoids & Positive \\
\hline 4. & Phenols & Positive \\
\hline 5. & Terpenoids & Positive \\
\hline 6. & Phytosterol & Positive \\
\hline 7. & Saponins & Positive \\
\hline 8. & Alkaloids & Negative \\
\hline 9. & Glycosides & Negative \\
\hline 10. & Tannins & Negative \\
\hline 11. & Diterpenes & Negative \\
\hline 12. & Carbhohydrate & Negative \\
\hline
\end{tabular}

Results of Phytochemical screening of the aqueous extract revealed the presence of steroid, terpenoids, saponins, tannins, lignin, flavonoids. Alcoholic extract showed the availability of alkaloids and devoid of saponins ${ }^{1}$. Similarly, the phytochemical screening for Ethanol extract was performed in which the phytoconstituents such as Resins, proteins, flavonoids, phenols, terpenoids, phytosterol and saponins were present. 
Quantitative estimations of total phenol and flavonoids

\section{Determination of total phenols and flavonoids}

The quantitative estimation of phenols and flavonoids were carried out in which flavonoid content was higher when compared to phenol. This proves these compounds might be responsible for potent antioxidant activity.

Table 7: Quantitative estimation of ethanol extract of Aegle marmelos

\begin{tabular}{|c|l|c|}
\hline S.No & Phytochemical & Results $(\boldsymbol{\mu g} / \mathbf{m g})$ \\
\hline 1. & Phenols & 9.510 \\
\hline 2. & Flavonoids & 92.43 \\
\hline
\end{tabular}

Total phenolic content was found to be $9.510 \mu \mathrm{g} / \mathrm{mg}$, flavonoid content was $92.43 \mu \mathrm{g} / \mathrm{mg}$. From the results, it is significant that due to presence of higher flavonoid content, the antioxidant activities were found to be higher for different extract of Aegle marmelos.

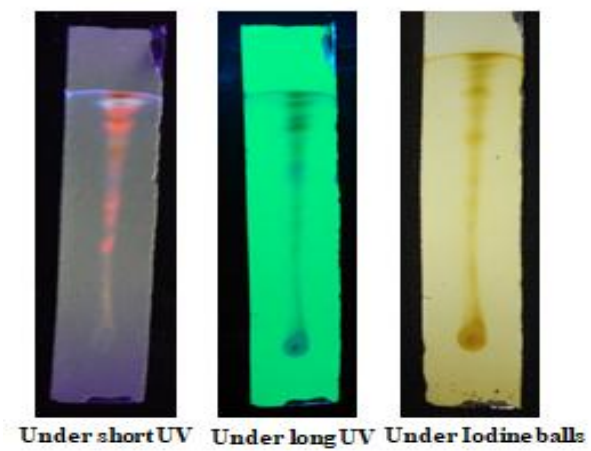

Figure.2: Compounds separation separated by Thin Layer Chromatography

\section{Thin Layer Chromatography analysis}

Thin layer chromatography analysis was carried out in the solvent system of Methanol (1mL) : Toluene $(1 \mathrm{~mL})$. The separated compounds in TLC were showed in Figure 2.

The separated active compounds were visualized in UV light (short and long) and iodine balls. The $\mathrm{R}_{\mathrm{f}}$ values of the separated compounds were measured and tabulated (Table 8).

Table 8: $\mathrm{R}_{\mathrm{f}}$ values of active compounds separated by Thin Layer Chromatography from the ethanol extract of Aegle marmelos

\begin{tabular}{|c|c|}
\hline \multirow{4}{*}{ Ethanol extract of } & $\begin{array}{c}\mathbf{R}_{\mathbf{f}} \text { values } \\
\text { (Under Iodine balls) }\end{array}$ \\
\cline { 2 - 2 } Aegle marmelos & 0.95 \\
\cline { 2 - 2 } & 0.91 \\
\cline { 2 - 2 } & 0.88 \\
\cline { 2 - 2 } & 0.82 \\
\cline { 2 - 2 } & 0.68 \\
\cline { 2 - 2 } & 0.53 \\
\cline { 2 - 2 } & 0.44 \\
\hline
\end{tabular}

Screening of crude extract for antibacterial activity

Agar Well diffusion assay (Eloff, 1998)

After incubation, the inhibition diameter was measured using zone scale. The maximum inhibition for ethanol extract of Aegle marmelos was against P.vulgaris $(18 \mathrm{~mm})$, when compared to other bacterial pathogens K.pneumoniae (16mm), B.subtilis (16mm).

Table 9: Antibacterial activity of ethanol extract of Aegle marmelos

\begin{tabular}{|c|c|c|c|c|c|}
\hline Test organisms & Standard & $250 \mu \mathrm{g} / \mathrm{mL}$ & $500 \mu \mathrm{g} / \mathrm{mL}$ & $750 \mu \mathrm{g} / \mathrm{mL}$ & $1000 \mu \mathrm{g} / \mathrm{mL}$ \\
\hline S.aureus & $19 \mathrm{~mm}$ & $14 \mathrm{~mm}$ & $14 \mathrm{~mm}$ & $14 \mathrm{~mm}$ & $15 \mathrm{~mm}$ \\
\hline K.pneumoniae & $20 \mathrm{~mm}$ & $14 \mathrm{~mm}$ & $15 \mathrm{~mm}$ & $15 \mathrm{~mm}$ & $16 \mathrm{~mm}$ \\
\hline P.vulgaris & $19 \mathrm{~mm}$ & $12 \mathrm{~mm}$ & $14 \mathrm{~mm}$ & $17 \mathrm{~mm}$ & $18 \mathrm{~mm}$ \\
\hline B.subtilis & $20 \mathrm{~mm}$ & $12 \mathrm{~mm}$ & $13 \mathrm{~mm}$ & $15 \mathrm{~mm}$ & $16 \mathrm{~mm}$ \\
\hline S.flexneri & $20 \mathrm{~mm}$ & $10 \mathrm{~mm}$ & $11 \mathrm{~mm}$ & $11 \mathrm{~mm}$ & $12 \mathrm{~mm}$ \\
\hline
\end{tabular}

Figure 3: Antibacterial activity of ethanol extract of Aegle marmelos by agar well diffusion method 
Phytochemicals such as flavonoids, phenols, sterols, terpenoids are secondary metabolites of plants that serves as defence mechanism against several microbes. In the current investigation, ethanol extract of Aegle marmelos possessed broad spectrum of antibiotic compounds.
Identification of bioactive compounds by Gas chromatography-Mass spectrometry analysis:

The GCMS analysis for ethanol extract of Aegle marmelos revealed the presence of phyto-active compounds such as Flavone, Longifolene-12, Phytol, tetradecanoic acid exhibiting biological activities.

Table 10: GC-MS analysis of ethanol extract of Aegle marmelos

\begin{tabular}{|c|c|c|c|c|c|}
\hline $\begin{array}{l}\text { S.N } \\
\mathbf{O}\end{array}$ & $\begin{array}{l}\text { COMPOUND } \\
\text { NAME }\end{array}$ & RT & COMPOUND STRUCTURE & $\begin{array}{l}\text { MOLECULAR } \\
\text { WEIGHT }\end{array}$ & $\begin{array}{c}\text { MOLECULAR } \\
\text { FORMULA } \\
(\mathrm{g} / \mathrm{mol})\end{array}$ \\
\hline 1 & Oleic acid & 19.42 & & 282.46 & $\mathrm{C}_{18} \mathrm{H}_{34} \mathrm{O}_{2}$ \\
\hline 2 & $\begin{array}{l}\text { Piperidine,3,3- } \\
\text { dimethyl- }\end{array}$ & 12.1 & & 113.20 & $\mathrm{C}_{7} \mathrm{H}_{15} \mathrm{~N}$ \\
\hline 3 & $\begin{array}{l}\text { Benzene, (1- } \\
\text { methylene butyl)- }\end{array}$ & 14.17 & & 146.23 & $\mathrm{C}_{11} \mathrm{H}_{14}$ \\
\hline 4 & Longifolene-12 & 15.9 & & 204.35 & $\mathrm{C}_{15} \mathrm{H}_{24}$ \\
\hline 5 & Flavone & 16.98 & & 222.24 & $\mathrm{C}_{15} \mathrm{H}_{10} \mathrm{O}_{2}$ \\
\hline 6 & Tetradecanoic acid & 17.68 & & 228.37 & $\mathrm{C}_{14} \mathrm{H}_{28} \mathrm{O}_{2}$ \\
\hline 7 & $\begin{array}{c}\text { Anthraquinone, } \\
\text { 2,3,6,7-tetra methyl- }\end{array}$ & 18.72 & & 264.28 & $\mathrm{C}_{17} \mathrm{H}_{12} \mathrm{O}_{3}$ \\
\hline 8 & $\begin{array}{l}\text { Heptadecanoic acid, } \\
16 \text { methyl, methyl } \\
\text { ester }\end{array}$ & 18.92 & & 298.51 & $\mathrm{C}_{19} \mathrm{H}_{38} \mathrm{O}_{2}$ \\
\hline 9 & $\begin{array}{l}\text { 11-Eicosenoic acid, } \\
\text { methyl ester }\end{array}$ & 20.48 & & 324.54 & $\mathrm{C}_{21} \mathrm{H}_{40} \mathrm{O}_{2}$ \\
\hline 10 & Phytol & 20.72 & & 296.53 & $\mathrm{C}_{20} \mathrm{H}_{40} \mathrm{O}$ \\
\hline 11 & $\begin{array}{c}\text { 2H-Naphtalen-1- } \\
\text { one,3,4-dihydro-6- } \\
\text { methoxy-2-(4- } \\
\text { methoxybenzylideno) }\end{array}$ & 21.42 & & 294.35 & $\mathrm{C}_{19} \mathrm{H}_{18} \mathrm{O}_{3}$ \\
\hline
\end{tabular}




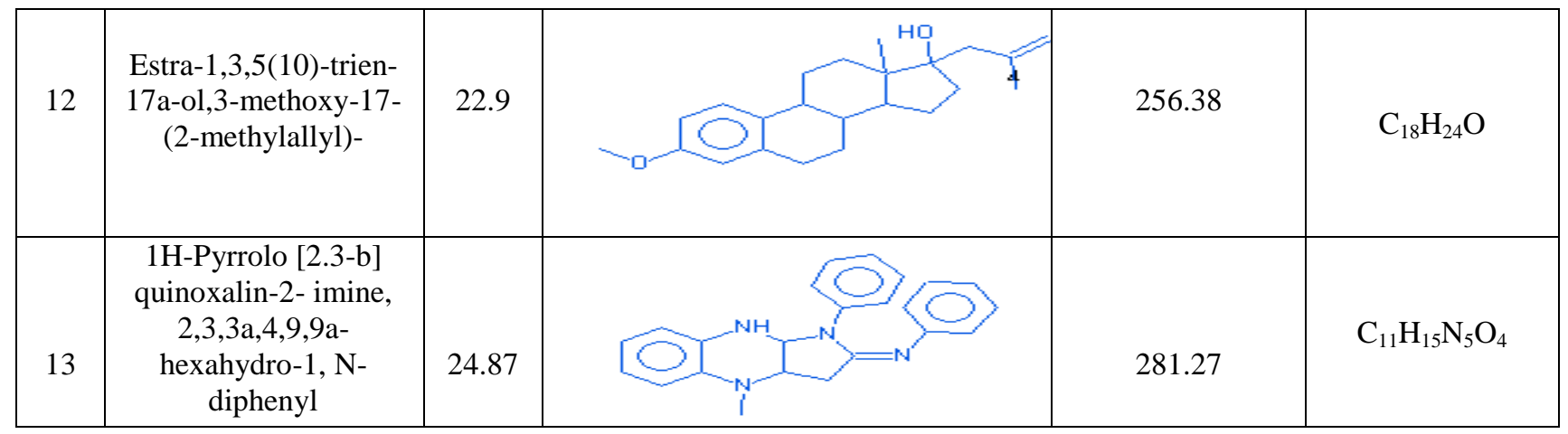

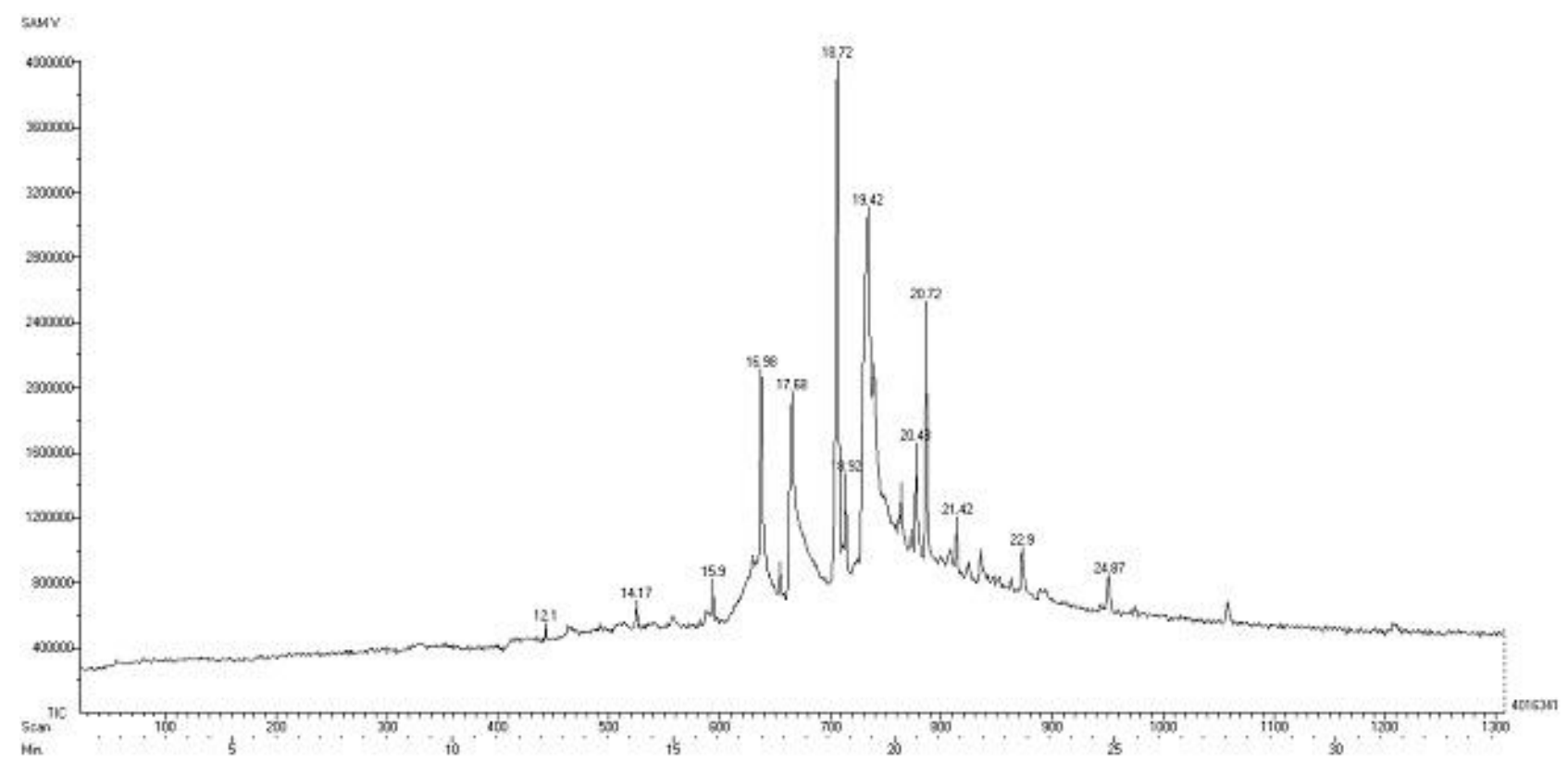

Graph 6: GCMS Chromatogram of ethanol extract of Aegle marmelos

Table 11: Bio-activity of ethanol extract of Aegle marmelos from GCMS analysis

\begin{tabular}{|c|c|c|}
\hline S.NO & $\begin{array}{c}\text { COMPOUND } \\
\text { NAME }\end{array}$ & PHARMACOLOGICAL ACTIVITY, REFERENCES ${ }^{15-22}$ \\
\hline 1 & Longifolene & $\begin{array}{l}\text { Anti-feedant } \\
\text { Antioxidant } \\
\text { Anti-cancer } \\
\text { Anti-inflammatory } \\
\text { Antibacterial }\end{array}$ \\
\hline 2 & Piperidine & $\begin{array}{l}\text { Antioxidant } \\
\text { Antimicrobial } \\
\text { Anti-cancer }\end{array}$ \\
\hline 3 & Phytol & $\begin{array}{l}\text { Aromatic Ingredient } \\
\text { Antinociceptive } \\
\text { Antioxidant } \\
\text { Antiallergic } \\
\text { Anti-inflammatory } \\
\text { Antimicrobial } \\
\text { Immunostimulant }\end{array}$ \\
\hline 4 & Flavone & $\begin{array}{l}\text { Production of Reactive Oxygen Species (ROS) can be reduced by flavonoids. } \\
\text { Relevance of plant defense mode of action is highly possible by flavonoids. } \\
\text { Formation of oxygen radicals can be prevented by flavonoids thereby inhibiting the enzyme } \\
\text { activity, }\end{array}$ \\
\hline
\end{tabular}




\section{CONCLUSION}

Different extracts of Aegle marmelos was evaluated for antioxidant and antibacterial activity against bacterial pathogens. Sensitivity against zone of inhibition was observed and found to be highest against 'Proteus vulgaris $18 \mathrm{~mm}$ as zone of inhibition. Phytochemical analysis revealed the presence of Resins, Proteins, Flavonoids, Phenols, Phytosterol, Saponins, Terpenoids in the Ethanol extract. Free radical scavenging activity by DPPH method possessed percentage of inhibition of $93.67 \%$ respectively followed by other extracts. Active compounds were identified by chromatography analysis

\section{REFERENCES}

1. Rajan S, Gokila M, Jency P, Brindha P, Sujatha RK, Antioxidant and phytochemical properties of Aegle marmelos fruit pulp: International journal of current pharmaceutical research, 2011; 3(2). ISSN-0975-7066.

2. Ariharan VN and Nagendra Prasad P, Mahavilva - a sacred tree with immense medicinal secrets: a mini review: Rasayan J Chemistry, 2013; 6(4):342-352.

3. Orwa C, Mutua A, Kindt R, Jamnadass R and Simons A, An introduction to Aegle Marmelos Agro Data, 2009, 4(2), 1-5.

4. Lambole VB, Murti K, Kumar U, Sandipkumar PB and Gajera $\mathrm{V}$, International Journal of Pharmaceutical Sciences Review and Research, 2010; 5:67-72.

5. Harborne JB, Phytochemical Methods, A guide to Modern Techniques of Plant analysis, second ed. Chapman and Hall, London. 1998, 54-84.

6. Soler-Rivas C, Espin JC, Wichers HJ, An easy and fast test to compare total free radical scavenger capacity of foodstuffs. Phytochem. Analysis, 2000; 11:1-9.

7. Khalaf NA, Shakya AK, Al-Othman A, El-Agbar Z, Farah H, Antioxidant activity of some common plants, Turk J. Biol, 2008; 32:51-55.

8. Prieto $\mathrm{P}$, Pineda M, Aguilar M, Spectrophotometric quantitation of antioxidant capacity through the formation of a phosphomolybdenum complex: Specific application to the determination of vitamin E. Analytical Biochemistry, 1999; 269:337-41.

9. Hennebelle T, Sahpaz S, Gressier B, Joseph H and Bailleul F, Antioxidant and Neurosedative Properties of Polyphenols and Iridoids from Lippia alba. Phytotherapy Research, 22; 2008:256-258.

10. Makari HK, Haraprasad N, Patil HS, Ravikumar, In Vitro Antioxidant Activity of The Hexane And Methanolic Extracts Of Cordia wallichii and Celastrus paniculata, The Internet J.Aesthetic and Antiaging Medicine, 2008; 1:1-10.

11. Spanos GA, and Wrosltad RE, Influence of processing and storage on the phenolic composition of Thompson seedless grape juice, Journal of Agricultural \& Food Chemistry, 1990; 38:1565-1571. by optimized solvent system. From the results obtained it is concluded that phytochemical present in Aegle marmelos of ethanol extract may be responsible for Antioxidant and antibacterial activity. GCMS analysis revealed the presence of active compounds like Piperidine, Flavone, Phytol and Longifolene as majority with various therapeutic applications.

\section{ACKNOWLEDGEMENT}

The authors wish to thank Armats Biotek Training and Research Institute and SAIF, IIT, Madras for providing necessary facilities needed for the research.

12. Liu $\mathrm{X}$, Dong $\mathrm{M}$, Chen $\mathrm{X}$, Jiang $\mathrm{M}$, Lv $\mathrm{X}$ and Yan $\mathrm{G}$, Antioxidant activity and phenolics of endophytic Xylaria sp. from Ginkgo biloba, Food Chemistry, 2007; 105:548-554.

13. Stahl E, Thin Layer Chromatography, 2nd ed., Springer Pvt. Ltd., New Delhi, 2005, 85.

14. Eloff JN, Which extractant should be used for the screening and isolation of antimicrobial components from plants, J. Ethnopharmacol, 1998; 60:1-8.

15. Kayser $\mathrm{O}$ and Kolodziej H, Antibacterial activity of extracts and constituents of Pelargonium sidoides and Pelargonium reniforme, Planta Med. 1997; 63:508-510.

16. Egan D, O'Kennedy R, Moran E, Cox D, Prosser E and Thornes D, The pharmacology, metabolism, analysis, and applications of coumarin and coumarin-related compounds, Drug Metabolism Reviews, 1990; 22(5):503-529.

17. Sergeant, L. \& May, E. Agonistsantagonists derived from desomorphine and metopon. Journal of Medicinal Chemistry, 1970; 13:1061.

18. Ryu KR, Choi JY, Chung S, Kim DH, Anti-scratching behavioral effect of the essential oil and phytol isolated from Artemisia princeps Pamp. in mice, Planta Med. 2011; 77(1):22-6.

19. McGinty D, Letizia CS, Api AM, Fragrance material review on phytol. Food Chem Toxicol. 2010; 48 Suppl (3):S59-63.

20. Lim SY, Meyer M, Kjonaas RA, Ghosh SK, Phytol-based novel adjuvants in vaccine formulation; assessment of safety and efficacy during stimulation of humoral and cell-mediated immune responses. J Immune Based Ther Vaccines, 2006; 30(4):6.

21. Inoue $\mathrm{Y}$, Hada $\mathrm{T}$, Shiraishi $\mathrm{A}$, Hirose $\mathrm{K}$, Hamashima $\mathrm{H}$, Kobayashi S, Biphasic effects of geranylgeraniol, teprenone, and phytol on the growth of Staphylococcus aureus, Antimicrob Agents Chemother, 2005; 49(5):1770-4.

22. Justyna M, Kamil K, Anna K, Flavonoids as Important Molecules of Plant Interactions with the Environment, Molecules, 2014; 19:16240-16265. 